\title{
Influence of the rhizosphere soils on essential elements of Ephedra sinica herbaceous stems
}

\author{
Zhe CAO ${ }^{1}$, Yujie YIN 1 , Fuying MAO ${ }^{1,2,3}$, Yanqun Peng ${ }^{1}$, Xinhui ZHANG ${ }^{1,2}$, Junyu LIANG ${ }^{4}$, Hongling TIAN , \\ Yunsheng $\mathrm{ZHAO}^{1,2,3^{*}}$
}

${ }^{1}$ Pharmacy College, Ningxia Medical University, Yinchuan, Ningxia, China, ${ }^{2}$ Ningxia Research Center of Modern Hui Medicine Engineering and Technology, Yinchuan, Ningxia, China, ${ }^{3}$ Key Laboratory of Hui Ethnic Medicine Modernization, Ministry of Education, Yinchuan, Ningxia, China ${ }^{4}$ College of Life Sciences of Northwest Normal University, Lanzhou, Ganshu, China, ${ }^{5}$ Institute of Industrial Crop Research, Shanxi Academy of Agricultural Sciences, Fenyang, Shanxi, China

\section{A B S T R A C T}

\begin{abstract}
Mineral elements serve as important components of medicinal herbs not only owing to their healing properties but also their nutritional supplement functions. In this study, 15 essential element contents of wild Ephedra sinica and its rhizosphere soil were measured by inductively coupled plasma mass spectroscopy. Influences of rhizosphere soil on these elements in plants were evaluated. Results showed that $\mathrm{N}, \mathrm{K}, \mathrm{Cl}, \mathrm{Sr}, \mathrm{Na}, \mathrm{Mn}, \mathrm{B}, \mathrm{Cu}$, and $\mathrm{Mo}$ contents in plants were all directly affected by one or more factors, including $\mathrm{pH}$ value, sand, silt, and organic matter contents. Herbaceous stems of $E$. sinica contained high contents of $\mathrm{N}, \mathrm{K}, \mathrm{S}$, and Ca and could accumulate $\mathrm{N}, \mathrm{S}, \mathrm{P}$, $\mathrm{Cl}, \mathrm{Sr}$, and $\mathrm{Mg}$ from soil with mean enrichment coefficients of 42.88, 34.37, 7.81, 4.38, 2.16, and 1.56, respectively. $\mathrm{N}$, $\mathrm{K}, \mathrm{Ca}$, Sr, Mn, $\mathrm{Zn}$, and $\mathrm{Cu}$ contents in the herbs were positively correlated with those in soil. Additionally, element prediction models were established to infer essential element contents of the herbaceous stems of $E$. sinica. This study provides scientific basis for mineral element regulation of $E$. sinica by adjusting soil fertility levels.
\end{abstract}

Keywords: Ephedra sinica; Essential elements; Herbaceous stems; Rhizosphere soil

\section{INTRODUCTION}

Ephedra herb (also known as Ma Huang), is one of the wellknown traditional Chinese medicines, and it has been widely used in crude form for over 3000 years. This herb is used as a diaphoretic, antiasthmatic, or diuretic to relieve colds, bronchial asthma, and edema (Abourashed et al., 2003). Ma Huang contributes to weight loss in obesity and enhances performance in endurance training, and is used as dietary supplement and weight loss product in the Western world (Khasbagan and Soyolt, 2007; Xin et al., 2015). Chinese Pharmacopoeia defines Ephedra sinica Stapf, Ephedra intermedia Schrenk C.A Mey., or Ephedra equisetina Bge as the official source of Ma Huang and indicates that the sum contents of ephedrine and pseudoephedrine measure not less than $0.8 \%$ (Pharmacopoeia., 2015). E. sinica, as the the primary medicinal species, is widely distributed in China, except in the lower reaches of Yangtze River and Pearl River Basin, and is especially common in northwest Chinese territories, such as Ningxia, Inner Mongolia, Xinjiang, and Gansu regions (Shen, 1995). E. sinica is an important component of desert grassland ecological systems, and its market demand is strong. Wild E. sinica resources have been severely reduced by excessive harvesting, and the Chinese government has enacted related legislations to strictly control the collection of wild E. sinica (Hong et al., 2011).

Plants require various elements, which are generally referred to as mineral elements, for their survival. Deficiency in these elements affects both plant quality and quantity. Carbon $(\mathrm{C})$, hydrogen $(\mathrm{H})$, oxygen $(\mathrm{O})$, nitrogen $(\mathrm{N})$, phosphorous $(\mathrm{P})$, sulfur $(\mathrm{S})$, boron $(\mathrm{B})$, chlorine $(\mathrm{Cl})$, potassium $(\mathrm{K})$, calcium $(\mathrm{Ca})$, magnesium $(\mathrm{Mg})$, manganese $(\mathrm{Mn})$, copper $(\mathrm{Cu})$, iron $(\mathrm{Fe})$, zinc $(\mathrm{Zn})$, molybdenum $(\mathrm{Mo})$, and nickel $(\mathrm{Ni})$ are plant essential elements and have a hand in many plant metabolic processes (Ohkama-Ohtsu and Wasaki, 2010). Many important functions of plant physiology are performed by these elements (Wang, 2012).

\footnotetext{
${ }^{*}$ Corresponding author:

Yunsheng ZHAO, Ningxia Research Center of Modern Hui Medicine Engineering and Technology, Ningxia Medical University,

Pharmacy College, No.692 Shengli South Street, Yinchuan 750004, Ningxia, China. Tel: +86-13619501878, Fax: +86-09516980193.

E-mail: zhaoyunsheng1886@163.com, zwhjzs@126.com.
}

Received: 24 January 2017; $\quad$ Accepted: 23 January 2018 
Mineral elements may not only influence the production of active ingredients by involving plant secondary metabolism (Nasim and Dhir, 2010; Singh and Garg, 1997; Suchacz and Wesolowski, 2013). but also play important parts as the curative materials (Han et al., 2006; Tuo et al., 2010). Soil provides the main mineral elements for plants. Some studies have measured the correlations between mineral elements in soils and the herbs grown on them. Chen et al. (2009) observed that the growth of Paeonia lactiflora improved at the moderate levels of $\mathrm{Fe}, \mathrm{Mn}, \mathrm{Cu}$, and $\mathrm{Zn}$ in soil, and the paeoniflorin content increased at the same mineral levels, but the opposite effect appeared at the higher levels of such elements.

Mineral elements are important for medicinal plant growth, they exert a direct influence on yields and organic compounds of herbs and also act as important curative materials. However, few studies had been conducted on essential element levels in E. sinica and its rhizosphere soil. Influences of soil elements and element composition on those of E. sinica remain unclear. Therefore, the present study (1) investigated the essential element characteristics of E. sinica and soil samples; (2) explored the relationship between soil and herb elements; and (3) revealed major controlling factors and established prediction models for essential element transfer from soil to E. sinica.

\section{MATERIALS AND METHODS}

\section{Materials}

Stems of wild E. sinica and their rhizosphere soils were collected in September and October 2012 from Ningxia, Inner Mongolia, Xinjiang, and Shanxi (Table 1). Plants were identified as authentic stems of E. sinica by associate Professor Minsheng Yan (Northwest Normal University, China).

Inductively coupled plasma mass spectroscopy (ICP-MS) multi-element standard stock solutions were provided by Beijing General Research Institute for Nonferrous Metals in China. Standard stock solution I $(100 \mathrm{mg} / \mathrm{L} \mathrm{B}, \mathrm{Cu}, \mathrm{Fe}$, $\mathrm{Mg}, \mathrm{Mn}, \mathrm{Sr}$, and Zn; GSB04-1767-2004) was diluted with nitric acid and hydrochloric acid solutions. Standard stock solution II (100 mg/L P, K, S; 20 mg/L Mo; GSB041764-2004) and solution III (1000 mg/ L Ca, $200 \mathrm{mg} / \mathrm{L}$ $\mathrm{Na}$; GSB04-2822-2011) were diluted with nitric acid solution. Standard stock solution V (1000 mg/L N; GSB 04-2837-2011(b)) and solution VI (1000 mg/L Cl; GSB 04-1770-2004) were diluted with deionized water solution. The internal standard solution $\left(100 \mathrm{mg} / \mathrm{L}{ }^{209} \mathrm{Bi},{ }^{72} \mathrm{Ge}\right.$, ${ }^{65} \mathrm{Zn},{ }^{175} \mathrm{Lu},{ }^{103} \mathrm{Rh},{ }^{45} \mathrm{Sc},{ }^{159} \mathrm{~Tb},{ }^{89} \mathrm{Y}$; GSB04-2828-2011) was diluted with nitric acid solution. Nitric acid $(\varrho 1.42 \mathrm{~g} / \mathrm{mL})$, hydrofluoric acid $(\varrho 1.15 \mathrm{~g} / \mathrm{mL})$, and hydrogen peroxide $(\rho 1.1 \mathrm{~g} / \mathrm{mL})$ were guaranteed reagents. The deionized water was prepared by Milli-Q Integral ultrapure water equipment (18.2 MS.cm, Millipore Co., Ltd. USA). All glass and plastic wares were cleaned with nitric acid and rinsed with deionized water before use.

\section{Sample preparation}

All plant samples were gently washed with deionized water, dried at $105^{\circ} \mathrm{C}$, and ground into fine powders (100 mesh). Afterward, fine powders of each plant sample were homogenized in a metal-free mortar and stored in paper bags at room temperature before analysis. Soil samples were treated identically to plant samples, except for washing, and stored in polyethylene bags before use.

For microwave-assisted digestion of plant samples (in triplicate) a Mars-6 Microwave System (CEM Co., Ltd, USA) was used to implement the following procedure: $1.0000 \mathrm{~g}$ of homogenized sample was weighed into a Teflon reaction vessel. The samples were digested with $5.0 \mathrm{~mL} \mathrm{HNO}_{3}+$ $3.0 \mathrm{~mL} \mathrm{H} \mathrm{O}_{2}$ in a three-step program $\left(1-120^{\circ} \mathrm{C} / 20 \mathrm{~min}\right.$, $2-160{ }^{\circ} \mathrm{C} / 20 \mathrm{~min}$, and $\left.3-180^{\circ} \mathrm{C} / 45 \mathrm{~min}\right)$. Microwaveassisted digestion of soil samples (in triplicate) followed the procedure: $0.5000 \mathrm{~g}$ of homogenized sample was weighed into a Teflon reaction vessel. The samples were digested with $5.0 \mathrm{~mL} \mathrm{HNO}_{3}+1.0 \mathrm{~mL} \mathrm{HF}+2.0 \mathrm{~mL} \mathrm{H}_{2} \mathrm{O}_{2}$ in a three-step program $\left(1-150^{\circ} \mathrm{C} / 25 \mathrm{~min}, 2-170^{\circ} \mathrm{C} / 30 \mathrm{~min}\right.$, and $\left.3-200^{\circ} \mathrm{C} / 80 \mathrm{~min}\right)$. After digestion, each plant or soil solution was evaporated to $0.5-1.0 \mathrm{~mL}$ on an electric hot plate at $140^{\circ} \mathrm{C}-160^{\circ} \mathrm{C}$. After cooling $(25 \mathrm{~min})$, the digests were diluted and transferred into a volumetric flask with $1 \mathrm{~mL}$ internal standard solution and up to $10 \mathrm{~mL}$ with deionized water.

\section{ICP-MS measurements}

Contents of essential elements in plants and soils digestion solutions were determined by ICP-MS (NexION 300D, PerkinElmer Instrument Co., USA). Instrument parameters were optimized as follows: radio frequency power of 1600 $\mathrm{W}$, plasma gas flow rate of $18.0 \mathrm{~L} / \mathrm{min}$, carrier gas flow rate of $1 \mathrm{~L} / \mathrm{min}$, sweeps/reading of 20 , scan mode of peak hopping, dwell time of $50 \mathrm{~ms}$, integral time of $1 \mathrm{~s}$, sampling depth of $8 \mathrm{~mm}$, and replicates of 5 .

\section{Soil characterization}

All soil samples were characterized according to $\mathrm{pH}$ value, organic matter (OM), cation exchange capacity (CEC), and soil mechanical composition (SMC, including sand, silt, and clay). Soil $\mathrm{pH}$ (1:2.5 soil-to-water ratio), OM content $\left(\mathrm{K}_{2} \mathrm{Cr}_{2} \mathrm{O}_{7}-\mathrm{H}_{2} \mathrm{SO}_{4}\right.$ electric sand-bath heating), CEC ( $\mathrm{HCl}-\mathrm{CH}_{3} \mathrm{CH}_{2} \mathrm{OH}-\mathrm{Ca}\left(\mathrm{CH}_{3} \mathrm{COO}\right)_{2}-\mathrm{NaOH}$ method), and SMC (hydrometer method) were analyzed according to the Chinese national standard methods of agricultural 
Cao, et al.

Table 1: Samples of E. sinica or their rhizosphere soils in the present work

\begin{tabular}{|c|c|c|c|c|}
\hline Samples & Source & Longitude & Latitude & Altitude (m) \\
\hline 1 & Gansu Gulang & E $103^{\circ} 06^{\prime} 48.50^{\prime \prime}$ & N $37^{\circ} 37^{\prime} 51.53^{\prime \prime}$ & 1736 \\
\hline 2 & Gansu Huachi & E $107^{\circ} 98^{\prime} 29.21^{\prime \prime}$ & N 36॰27’21.10” & 1213 \\
\hline 3 & Gansu Qingyang Xifeng & E $107^{\circ} 39^{\prime} 49.21^{\prime \prime}$ & N 35॰31'10.10" & 1190 \\
\hline 4 & Gansu Shandan & E $101^{\circ} 23^{\prime} 10.02^{\prime \prime}$ & N 3803’25.19”' & 2898 \\
\hline 5 & Inner Mongolia, Chifengbalin & E 118 38'10" & N 43²2’26”' & 740 \\
\hline 6 & Inner Mongolia, Etuokeqianqi & E $107^{\circ} 30^{\prime} 43.58^{\prime \prime}$ & N 38²9’51.58” & 1349 \\
\hline 7 & Inner Mongolia, Wengniuteqi & E $118^{\circ} 59^{\prime} 16^{\prime \prime}$ & N 4258'24" & 670 \\
\hline 8 & Ningxia Lingwu & E $106^{\circ} 24^{\prime} 27.80^{\prime \prime}$ & N $37^{\circ} 53^{\prime} 51.81^{\prime \prime}$ & 1250 \\
\hline 9 & Ningxia Qingtongxia & E 106 $09^{\prime} 21.10^{\prime \prime}$ & N 38²1'06.63" & 1123 \\
\hline 10 & Ningxia Yanchi & E $107^{\circ} 23^{\prime} 52.69^{\prime \prime}$ & N $37^{\circ} 47^{\prime} 52.64^{\prime \prime}$ & 1352 \\
\hline 11 & Shanxi Datong Zhouzhuang & E $113^{\circ} 25^{\prime} 26^{\prime \prime}$ & N 4008' ${ }^{\prime \prime}$ & 1170 \\
\hline 12 & Shanxi Tianzhen & E 11354'32" & N 4016’37' & 1672 \\
\hline 13 & Shanxi Youyu & E $111^{\circ} 53^{\prime} 26^{\prime \prime}$ & N $39^{\circ} 27^{\prime} 54^{\prime \prime}$ & 1547 \\
\hline 14 & Xinjiang Heshuo, Quhui & E 8710'06" & N 42 $15^{\prime} 30^{\prime \prime}$ & 1123 \\
\hline
\end{tabular}

chemistry in soil (MOC, 2004; MOA, 1988; MOA, 2006a; MOA, 2006b; MOA, 2007).

\section{Prediction models establishment for element transfer}

To predict essential element transfer from soil to E. sinica, a regression function was used:

$\log \left[C_{\text {plant }}\right]=a+b \log \left[C_{\text {soil }}\right]$

where $C_{\text {plant }}$ was one specific element content in E. sinica stems, $C_{\text {soil }}$ referred to the total content of soil elements which are significantly associated with this element in E. sinica $(P<0.05)$, and $a$ and $b$ were regression coefficient. This regression function also applied to soil characterizations, such as sand, silt, $\mathrm{OM}$ content, and $\mathrm{pH}$ value (Cheng et al., 2015).

\section{Statistical analysis}

Data were analyzed by SPSS 21.0 software (International Business Machines Corporation, USA), and all values were expressed as mean values. $P$ values less than 0.05 and 0.01 were considered statistically significant and statistically highly significant, respectively.

\section{RESULTS AND DISCUSSION}

\section{Method validation for elemental analysis}

Measurements were accomplished by external calibration using aqueous mixed standard substances. Slopes of calibration curves of all analytes exhibited good sensitivity, with their correlation coefficients all reaching beyond 0.9995. Precision, which was expressed as relative standard deviation (RSD), ranged from $0.02 \%$ to $1.1 \%$. Withinday repeatability was $<3.4 \%$. Tables 3 and 4 summarize the limits of detection (LOD) determined in digestion solutions of soils and plants samples for ICP-MS. The recoveries determined with plant or soil sample 1 ranged from $94 \%$ to $115 \%$ for ICP-MS.

\section{Soil characteristics}

Soil SMC (sand, silt, and clay), $\mathrm{pH}$ value, OM, and CEC were measured, and the detailed results per soil were listed in Table 2. $\mathrm{pH}$ values varied in a narrow range (7.36 to 8.50, i.e., neutral to moderately alkaline). $\mathrm{pH}$ value influenced soil protons, which were usually present in $\mathrm{H}_{2} \mathrm{O}$ solutions ligated to ionic exchange structures of soil components. Soil CEC ranged from $8.85 \mathrm{mmol} / \mathrm{kg}$ to $54.99 \mathrm{mmol} / \mathrm{kg}$. CEC provided information on potential of soils to bind or to release cations (as nutrients or pollutants). Average OM content of all soil samples reached $7.39 \mathrm{~g} / \mathrm{kg}$ and ranged from $0.78 \mathrm{~g} / \mathrm{kg}$ to $22.11 \mathrm{~g} / \mathrm{kg}$ with generally high coefficients of variation. Soil SMC (sand $2-0.05 \mathrm{~mm}$, silt $0.05-0.002 \mathrm{~mm}$, clay $<0.002 \mathrm{~mm}$ ) exhibited significant variability in SMC distribution (37.0-211.0 g/ $\mathrm{kg}$ clay, $2.0-66.8 \mathrm{~g} / \mathrm{kg}$ silt, $760.2-961 \mathrm{~g} / \mathrm{kg}$ sand).

All these variables were important parameters influencing elemental contents in plant samples. In this study, parameters of rhizosphere soils differed according to the collected locations. These influencing factors created a chemical environment conducive for plant growth.

\section{Element contents of soil samples}

Table 3 showed the element contents with LOD in 14 rhizosphere soil samples. The order of average contents was $\mathrm{Ca}>\mathrm{Na}>\mathrm{K}>\mathrm{Fe}>\mathrm{Mg}>\mathrm{Mn}>\mathrm{N}>\mathrm{P}>\mathrm{S}>\mathrm{Sr}>$ $\mathrm{Zn}>\mathrm{Cl}>\mathrm{B}>\mathrm{Cu}>\mathrm{Mo}$. Contents of total elements varied considerably from $13447.75 \mathrm{mg} / \mathrm{kg}$ to $137553.94 \mathrm{mg} / \mathrm{kg}$, with an average of $69513.62 \mathrm{mg} / \mathrm{kg}$. The highest contents were observed for Ca with an average of $50070.91 \mathrm{mg} / \mathrm{kg}$ and accounted for $72.03 \%$ of total elements. RSD of element contents approximated $42 \%$, which is within the acceptable range for inhomogeneous soil specimens. For each sampling site (soil samples 1-14), RSD values ranged from $2.2 \%$ to $4.9 \%$. High variations were observed for $\mathrm{Ca}$ and $\mathrm{P}$, and these elements were strongly related to local bedrock composition. RSD measuring less than 10\% 
Table 2: The characteristics data of the investigated soils $(n=3)$

\begin{tabular}{|c|c|c|c|c|c|c|}
\hline \multirow[t]{2}{*}{ Samples } & Sand $(g / k g)$ & Silt (g/kg) & Clay $(\mathrm{g} / \mathrm{kg})$ & \multirow[t]{2}{*}{ PH } & \multirow{2}{*}{$\frac{\mathrm{OM}}{(\mathrm{g} / \mathrm{kg})}$} & \multirow{2}{*}{$\begin{array}{c}\text { CEC } \\
(\mathrm{mmol} / \mathrm{kg})\end{array}$} \\
\hline & $2-0.05 \mathrm{~mm}$ & $0.05-0.002 \mathrm{~mm}$ & $<0.002 \mathrm{~mm}$ & & & \\
\hline Soil 1 & $865.4 \pm 25.96$ & $18.8 \pm 0.62$ & $115.8 \pm 3.47$ & $8.06 \pm 0.28$ & $3.67 \pm 0.12$ & $34.38 \pm 1.24$ \\
\hline Soil 2 & $760.2 \pm 24.33$ & $28.8 \pm 0.92$ & $211 \pm 6.54$ & $7.88 \pm 0.27$ & $9.21 \pm 0.31$ & $19.29 \pm 0.73$ \\
\hline Soil 3 & $798.2 \pm 22.34$ & $66.8 \pm 2.07$ & $135 \pm 4.32$ & $7.78 \pm 0.28$ & $16.2 \pm 0.57$ & $10.24 \pm 0.37$ \\
\hline Soil 4 & $852.2 \pm 22.16$ & $46.8 \pm 1.5$ & $101 \pm 3.23$ & $7.84 \pm 0.27$ & $22.1 \pm 0.71$ & $14.79 \pm 0.55$ \\
\hline Soil 5 & $952.2 \pm 22.85$ & $8.8 \pm 0.31$ & $39 \pm 1.29$ & $7.97 \pm 0.28$ & $7.49 \pm 0.25$ & $15.34 \pm 0.55$ \\
\hline Soil 6 & $924.6 \pm 26.81$ & $22.8 \pm 0.75$ & $52.6 \pm 1.74$ & $8.5 \pm 0.29$ & $5.29 \pm 0.17$ & $27.62 \pm 1.02$ \\
\hline Soil 7 & $877.4 \pm 28.08$ & $10 \pm 0.35$ & $112.6 \pm 3.49$ & $7.76 \pm 0.26$ & $7.7 \pm 0.25$ & $21.68 \pm 0.76$ \\
\hline Soil 8 & $961 \pm 28.83$ & $2 \pm 0.07$ & $37 \pm 1.18$ & $8.2 \pm 0.28$ & $0.78 \pm 0.03$ & $12.91 \pm 0.46$ \\
\hline Soil 9 & $943.4 \pm 27.36$ & $11.2 \pm 0.37$ & $45.4 \pm 1.45$ & $8.09 \pm 0.27$ & $1.74 \pm 0.06$ & $16.39 \pm 0.61$ \\
\hline Soil 10 & $903.8 \pm 27.11$ & $10.40 \pm 0.35$ & $85.8 \pm 2.66$ & $8.5 \pm 0.3$ & $1.57 \pm 0.05$ & $8.85 \pm 0.33$ \\
\hline Soil 11 & $886.6 \pm 27.48$ & $31.6 \pm 1.01$ & $81.8 \pm 2.62$ & $8.18 \pm 0.28$ & $6.61 \pm 0.21$ & $16.18 \pm 0.6$ \\
\hline Soil 12 & $899 \pm 27.87$ & $18.4 \pm 0.59$ & $82.6 \pm 2.64$ & $7.48 \pm 0.25$ & $11.2 \pm 0.37$ & $22.37 \pm 0.85$ \\
\hline Soil 13 & $915 \pm 27.45$ & $20 \pm 0.68$ & $65 \pm 2.14$ & $8.1 \pm 0.27$ & $5.39 \pm 0.17$ & $30.92 \pm 1.12$ \\
\hline Soil 14 & $932.6 \pm 27.98$ & $11.2 \pm 0.38$ & $56.2 \pm 1.8$ & $7.36 \pm 0.25$ & $4.45 \pm 0.15$ & $54.99 \pm 1.98$ \\
\hline Means & 890.83 & 21.97 & 87.20 & 7.98 & 7.39 & 21.85 \\
\hline
\end{tabular}

Table 3: Elemental contents in soil samples (Content in $\mathrm{mg} / \mathrm{kg}, \mathrm{n=3}$ ).

\begin{tabular}{|c|c|c|c|c|c|c|c|c|c|c|c|c|}
\hline \multirow[t]{2}{*}{ LOD } & \multicolumn{2}{|l|}{$\mathrm{Ca}$} & \multicolumn{2}{|c|}{$\mathrm{Na}$} & \multirow{2}{*}{\multicolumn{2}{|c|}{$\begin{array}{c}\mathrm{K} \\
0.001\end{array}$}} & $\mathrm{Fe}$ & \multicolumn{2}{|c|}{ Mg } & \multicolumn{2}{|c|}{ Mn } & $\mathbf{N}$ \\
\hline & \multicolumn{2}{|l|}{0.004} & \multicolumn{2}{|c|}{0.005} & & & 0.002 & \multicolumn{2}{|c|}{0.004} & \multicolumn{2}{|c|}{0.002} & 0.010 \\
\hline Soil 1 & \multicolumn{2}{|c|}{$37170.58 \pm 1077.95$} & \multicolumn{2}{|c|}{$5160.00 \pm 165.12$} & \multicolumn{2}{|c|}{$4696.75 \pm 145.6$} & $3356.81 \pm 87.28$ & \multicolumn{2}{|c|}{$1675.81 \pm 53.63$} & \multicolumn{2}{|c|}{$434.36 \pm 16.51$} & $400.55 \pm 14.02$ \\
\hline Soil 2 & \multicolumn{2}{|c|}{$63752.05 \pm 1912.6$} & \multicolumn{2}{|c|}{$5094.75 \pm 168.13$} & \multicolumn{2}{|c|}{$7860.21 \pm 227.95$} & $4761.8 \pm 119.05$ & \multicolumn{2}{|c|}{$2561.6 \pm 79.41$} & \multicolumn{2}{|c|}{$640.93 \pm 23.71$} & $508.35 \pm 18.3$ \\
\hline Soil 3 & $86925.45 \pm 269$ & 4.69 & 4898.25 & \pm 146.94 & 8906 & $6.17 \pm 276.09$ & $5437.09 \pm 146.8$ & $2614.2 \pm$ & 75.81 & 763. & $41 \pm 29.77$ & $534.03 \pm 19.76$ \\
\hline Soil 4 & $80086.78 \pm 24$ & 2.6 & $5338 \pm$ & 165.48 & 1022 & $24.7 \pm 296.52$ & $6551.4 \pm 170.34$ & $3297.34 \pm$ & 102.22 & 945. & $39 \pm 34.98$ & $766.6 \pm 26.06$ \\
\hline Soil 5 & $2194.78 \pm 68$ & & 4159.25 & \pm 128.94 & 384 & $44.8 \pm 115.35$ & $1608.62 \pm 45.04$ & $760.23 \pm$ & 22.05 & 241. & $16 \pm 9.16$ & $309.11 \pm 10.51$ \\
\hline Soil 6 & $57531.16 \pm 17$ & 25.9 & 10543.5 & \pm 316.31 & 528 & $88.4 \pm 153.36$ & $3080.36 \pm 83.17$ & $1551.6 \pm$ & 46.55 & 355. & $31 \pm 13.15$ & $432.57 \pm 15.14$ \\
\hline Soil 7 & $14713.99 \pm 45$ & 5.13 & 10693.75 & \pm 310.12 & 430 & $08.8 \pm 133.58$ & $3568.74 \pm 99.92$ & $913.72 \pm$ & 28.33 & 483. & $04 \pm 18.84$ & $472.55 \pm 17.01$ \\
\hline Soil 8 & $16364.11 \pm 49$ & 4.58 & 4505.50 & \pm 126.15 & 426 & $63.5 \pm 123.64$ & $4554.6 \pm 118.42$ & $1239.3 \pm$ & 7.18 & 430. & $41 \pm 15.93$ & $387.45 \pm 13.17$ \\
\hline Soil 9 & $17504.37 \pm 50$ & 7.63 & 5741.5 & \pm 172.25 & 463 & $33.2 \pm 129.73$ & $3557.40 \pm 88.94$ & $1127.90 \pm$ & 36.09 & 39 & $2 \pm 14.53$ & $389.32 \pm 14.02$ \\
\hline Soil 10 & $34785.15 \pm 104$ & 3.55 & 4595.75 & \pm 147.17 & 3958 & $8.89 \pm 122.73$ & $4172.7 \pm 116.84$ & $1340.4 \pm$ & 1.55 & 457.8 & $32 \pm 17.85$ & $471.29 \pm 16.5$ \\
\hline Soil 11 & $43626.69 \pm 130$ & 8.81 & 4905.75 & \pm 142.27 & 4111 & $1.76 \pm 119.24$ & $3724.3 \pm 100.56$ & 1381.1 & & 327. & $4 \pm 12.12$ & $344.07 \pm 11.7$ \\
\hline Soil 12 & $92748.06 \pm 26$ & 39.7 & 5471.50 & \pm 153.2 & 4320 & $0.85 \pm 120.98$ & $6007.4 \pm 150.19$ & $1976.8 \pm$ & 1.28 & 409. & $03 \pm 14.73$ & $469.39 \pm 15.49$ \\
\hline Soil 13 & $43518.80 \pm 134$ & 9.08 & 6365.00 & 190.95 & 4022 & $2.18 \pm 120.67$ & $4474.7 \pm 120.82$ & $1385.8 \pm$ & 1.57 & 505. & \pm 19.71 & $418.27 \pm 14.22$ \\
\hline Soil 14 & $110070.7 \pm 319$ & 2.05 & 13474.25 & \pm 377.28 & 7724 & $4.43 \pm 216.28$ & $3147.16 \pm 81.83$ & $1648.6 \pm$ & & 443. & $29 \pm 16.4$ & $455.32 \pm 16.39$ \\
\hline means & 50070.91 & & 649 & 3.20 & & 5583.21 & 4143.11 & 1676 & & & 87.84 & 454.21 \\
\hline RSD & & & & & & 38.27 & 31.13 & & & & & 23.98 \\
\hline LOD & $S$ & & $\mathbf{P}$ & $\mathrm{Sr}$ & & $\mathrm{Zn}$ & $\mathrm{Cl}$ & B & & & Mo & SUM \\
\hline & 0.010 & & .002 & 0.002 & & 0.002 & 0.010 & 0.006 & & & 0.003 & \\
\hline Soil 1 & $116.82 \pm 4.67$ & & $.46 \pm 5.12$ & $90.63 \pm 3.5$ & & $60.41 \pm 2.42$ & $59.56 \pm 2.38$ & $53.85 \pm 1.94$ & 23.79 & \pm 0.69 & $0.92 \pm 0.04$ & .30 \\
\hline Soil 2 & $233.03 \pm 9.09$ & & $.58 \pm 9.81$ & $152 \pm 5.78$ & & $91.4 \pm 3.47$ & $67.69 \pm 2.64$ & $36.99 \pm 1.29$ & & & $1.07 \pm 0.05$ & 86066.83 \\
\hline Soil 3 & $80.69 \pm 3.31$ & 327 & $.2 \pm 11.45$ & $138.06 \pm 4.8$ & & $103.13 \pm 4.12$ & $65.02 \pm 2.6$ & $60.58 \pm 2.06$ & 38.95 & 1.17 & $1.06 \pm 0.05$ & 110893.30 \\
\hline Soil 4 & $75.56 \pm 2.95$ & & $86 \pm 13.71$ & $90.21 \pm 3.1$ & & $130.94 \pm 4.98$ & $65.6 \pm 2.56$ & $51.66 \pm 2.06$ & & & $1.87 \pm 0.08$ & 108066.84 \\
\hline Soil 5 & $105.62 \pm 4.12$ & & .691 .66 & $24.58 \pm 0.9$ & & $45.52 \pm 1.78$ & $37.91 \pm 1.36$ & $64.25 \pm 2.25$ & 7.3 & .21 & $0.81 \pm 0.04$ & 13447.75 \\
\hline Soil 6 & $189.73 \pm 7.59$ & 104 & $.28 \pm 3.65$ & $155.44 \pm 5.9$ & & $58.96 \pm 2.36$ & $57.09 \pm 2.28$ & $60.16 \pm 2.05$ & 18.3 & 0.51 & $1.44 \pm 0.06$ & 79428.38 \\
\hline Soil 7 & $323.25 \pm 13.25$ & & $86 \pm 2.02$ & $34.15 \pm 1.3$ & & $48.60 \pm 1.8$ & $85.52 \pm 3.51$ & $62.85 \pm 2.26$ & 14.3 & $=0.42$ & $1.38 \pm 0.06$ & 35782.64 \\
\hline Soil 8 & $120.06 \pm 4.68$ & & $54 \pm 2.32$ & $44.04 \pm 1.5$ & & $45.99 \pm 1.75$ & $53.17 \pm 2.6$ & $51.80 \pm 1.92$ & 15.08 & \pm 0.44 & $0.93 \pm 0.04$ & 32140.57 \\
\hline Soil 9 & $203.82 \pm 7.75$ & & $74 \pm 3.62$ & $42.18 \pm 1.5$ & & $43.94 \pm 1.58$ & $39.41 \pm 1.69$ & $37.25 \pm 1.23$ & 13. & \pm 0.4 & $1.77 \pm 0.08$ & 33825.99 \\
\hline Soil 10 & $99.93 \pm 3.9$ & & $95 \pm 2.85$ & $126.76 \pm 4.8$ & & $35.91 \pm 1.44$ & $66.18 \pm 2.71$ & $28.48 \pm 1$ & 15.65 & \pm 0.49 & $1.21 \pm 0.05$ & 50240.16 \\
\hline Soil 11 & $54.32 \pm 2.17$ & 208 & $.88 \pm 7.31$ & $73.76 \pm 2.9$ & & $53.97 \pm 2$ & $36.39 \pm 1.56$ & $37.35 \pm 1.27$ & 27.20 & \pm 0.76 & $1.65 \pm 0.08$ & 58914.87 \\
\hline Soil 12 & $98.27 \pm 4.03$ & 237 & $.82 \pm 8.56$ & $128.93 \pm 4$ & & $72.45 \pm 2.83$ & $65.11 \pm 2.73$ & $52.08 \pm 1.82$ & 40.19 & \pm 1.17 & $1.52 \pm 0.07$ & 112099.56 \\
\hline Soil 13 & $194.23 \pm 7.57$ & & $.42 \pm 6.93$ & $71.71 \pm 2.8$ & & $54.41 \pm 1.96$ & $32.21 \pm 1.29$ & $32.35 \pm 1.16$ & 25.87 & \pm 0.78 & $2.17 \pm 0.09$ & 61290.61 \\
\hline Soil 14 & $112.34 \pm 4.38$ & 170 & $.04 \pm 5.95$ & $116.31 \pm 4.4$ & & $62.02 \pm 2.48$ & $58.73 \pm 2.64$ & $25.75 \pm 0.88$ & 43.03 & \pm 1.25 & $1.87 \pm 0.08$ & 137553.94 \\
\hline means & 143.41 & & 69.67 & 92.05 & & 64.83 & 56.40 & 46.81 & & & 1.41 & 69513.62 \\
\hline RSD & 52.18 & & 61.97 & 48.89 & & 40.93 & 26.70 & 28.54 & 54. & & 30.00 & 53.19 \\
\hline
\end{tabular}


implied low variability, whereas RSD of more than $90 \%$ indicated extensive variability as reported by Zhang et al. (2007). A moderate variability was detected in most element contents of soil samples.

In general, $\mathrm{Cu}, \mathrm{Fe}, \mathrm{Mn}, \mathrm{Sr}$, and $\mathrm{Zn}$ are categorized as plant micro elements $(<0.01 \%$ of plant dry weight) and play important roles in soil fertility. Normal contents of these elements in soil were of significant interest as background values, and they were needed for assessment of the degree of soil contamination to some extent. $\mathrm{Cu}$ content was below the limit for agricultural soil in China $(100 \mathrm{mg} / \mathrm{kg})$, France and Canada. Zn content was considerably below the maximum regulated soil contents in China and France (AFNOR, 1996; CEPA, 2006; CCME, 2012). Fe, Mn, and Sr contents were below the reference values for agricultural soil according to Kabata-Pendias and Mukhrjee (2007). The study areas were not contaminated by the investigated metal elements (i.e., $\mathrm{Cu}, \mathrm{Fe}, \mathrm{Mn}, \mathrm{Sr}$, and $\mathrm{Zn}$ ).

\section{Element contents of plant samples}

Table 4 listed the elemental contents in plant samples along with LOD. The order of average element contents was $\mathrm{N}>\mathrm{K}>\mathrm{S}>\mathrm{Ca}>\mathrm{Mg}>\mathrm{P}>\mathrm{Fe}>\mathrm{Cl}>\mathrm{Sr}>\mathrm{Na}>$ $\mathrm{Mn}>\mathrm{B}>\mathrm{Zn}>\mathrm{Cu}>\mathrm{Mo}$. Contents of total elements varied from $21,216.91 \mathrm{mg} / \mathrm{kg}$ to $54,426.02 \mathrm{mg} / \mathrm{kg}$, with an average of $34,863.55 \mathrm{mg} / \mathrm{kg}$. The highest contents were observed for $\mathrm{N}$, the values varied from $12,523.58 \mathrm{mg} / \mathrm{kg}$ to $33,304.26 \mathrm{mg} / \mathrm{kg}$, and accounted for $55.98 \%$ of total element contents. Macro elements (N, P, K, Ca, Mg, and S) accounted for $97.05 \%$ of the total elements, whereas micro elements (Fe, B, Mn, $\mathrm{Zn}, \mathrm{Cu}, \mathrm{Mo}, \mathrm{Cl}, \mathrm{Na}$, and $\mathrm{Sr}$ ) were relatively rare. $\mathrm{P}$ is an important macro element in plant. However, P content (mean $836.40 \mathrm{mg} / \mathrm{kg}$ ) was lower than those of other macro elements (mean $\geq 2267.01 \mathrm{mg} / \mathrm{kg}$ ). Fe content was the highest among micro elements and ranged from $120.27 \mathrm{mg} / \mathrm{kg}$ to $760.71 \mathrm{mg} / \mathrm{kg}$, with an average of $443.37 \mathrm{mg} / \mathrm{kg}$. Fe content in all samples reached above the reference values $(17-50 \mathrm{mg} / \mathrm{kg}$ ) according to KabataPendias and Mukhrjee (2007). Some specific mechanisms might be observed for E. sinica during absorption of additional $\mathrm{Fe}$ from rhizosphere soil. $\mathrm{Cl}$ content ranged from $102.36 \mathrm{mg} / \mathrm{kg}$ to $331.92 \mathrm{mg} / \mathrm{kg}$ in samples from different sites and was the second highest among the micro elements. Plants only require $\mathrm{Cl}$ in small amounts (Sun et al., 2013), but $\mathrm{Cl}$ content was high in E. sinica. Sr levels were between 80.79 and $269.36 \mathrm{mg} / \mathrm{kg}$. Na contents were between 29.95 and $194.41 \mathrm{mg} / \mathrm{kg}$. Minimum and maximum levels of B measured 10.88 and $41.86 \mathrm{mg} / \mathrm{kg}$, respectively. Mo contents of samples varied to a lesser extent.

All these elements and other organic compounds all serve as important pharmacodynamic material bases of medicinal plants (Qin, 2011). However, considerable element contents in plants fall within certain limits, and excessive metal elements may be harmful for humans. In our study, $\mathrm{Zn}$ contents ranged from $10.28 \mathrm{mg} / \mathrm{kg}$ to $28.26 \mathrm{mg} / \mathrm{kg}$ and were within the reference value of plant foodstuffs (Kabata-Pendias and Pendias, 2011). Cu contents obtained from different sites ranged from $2.07 \mathrm{mg} / \mathrm{kg}$ to $6.14 \mathrm{mg} /$ $\mathrm{kg}$ and were within the permissible limit proposed by WHO (1998). The contents of Mn were between 7.23 and $58.74 \mathrm{mg} / \mathrm{kg}$. In sample 4, Mn content was above the reference value $(27-50 \mathrm{mg} / \mathrm{kg}$ ) of Kabata-Pendias and Mukhrjee for plants in agricultural lands. Studies found that nutritional supplementary with mineral elements, especially $\mathrm{Cu}$ and $\mathrm{Mn}$, should be more suitable and be recommended for patients suffering chemotherapy to sustain nutrient homoeostasis (Kabata-Pendias and Mukhrjee, 2007; Akutsu et al., 2012).

\section{Element uptake and accumulation of $E$. sinica}

Availability of mineral elements to plants is regulated by soil characteristics, plant biological properties, climate conditions, etc. Soil characteristics, such as sand, silt, $\mathrm{OM}$, and $\mathrm{pH}$ value, have important effects on absorption and transfer of specific elements in rhizosphere soil. We investigated the relationships between contents of essential elements in the soils and E. sinica grown on them. The measured results were shown in Table 5. Correlation analysis showed that sand, silt, and OM of the soils were more importance than other factors for E. sinica. For example, content of soil silt was positively related with the contents of $\mathrm{N}, \mathrm{K}, \mathrm{Cl}, \mathrm{Na}, \mathrm{Mn}, \mathrm{B}, \mathrm{Cu}$, and $\mathrm{Mo}$ in plant, but content of soil sand was negatively proportional to $\mathrm{N}, \mathrm{K}, \mathrm{Cl}, \mathrm{Sr}, \mathrm{Na}, \mathrm{B}$, and $\mathrm{Cu}$ contents. OM content was positively correlated with $\mathrm{N}, \mathrm{K}, \mathrm{Na}, \mathrm{Mn}, \mathrm{B}, \mathrm{Cu}$, and $\mathrm{Mo}$ contents in plants, whereas $\mathrm{Mn}$ content was affected by $\mathrm{pH}$ value of soil.

Among the 240 correlations analyzed between element contents from E. sinica and their rhizosphere soils (Table 6), 111 were statistically significant, and N, K, Ca, Sr, Mn, Zn, and $\mathrm{Cu}$ contents in plants were correlated to those in soils.

Given the high variation of soil composition, the exact calculation of plant enrichment coefficients (enrichment coefficient $=$ average element content in plants $/$ average element content in soils) was not considered justifiable. Nevertheless, general conclusions can be drawn regarding mineral uptake and accumulation behavior upon comparison of soil and plant elemental contents. The order for element enrichment coefficients was $\mathrm{N}$ $>\mathrm{S}>\mathrm{P}>\mathrm{Cl}>\mathrm{Sr}>\mathrm{Mg}>\mathrm{K}>\mathrm{Mo}>\mathrm{B}>\mathrm{Zn}>\mathrm{Cu}>$ $\mathrm{Ca}=\mathrm{Fe}>\mathrm{Mn}>\mathrm{Na}$. Mean contents of N, S, P, Cl, Sr, and $\mathrm{Mg}$ in plants were higher than those in soils, whereas higher mean contents of the other nine minerals were observed in soils. Results demonstrated that E. sinica could 
Table 4: Elemental contents in plant samples (Content in $\mathrm{mg} / \mathrm{kg}, \mathrm{n}=3$ ).

\begin{tabular}{|c|c|c|c|c|c|c|c|c|c|c|c|}
\hline \multirow[t]{2}{*}{ LOD } & \multicolumn{2}{|l|}{$\mathbf{N}$} & \multicolumn{2}{|l|}{$\mathbf{K}$} & \multicolumn{2}{|c|}{$\mathrm{S}$} & \multirow{2}{*}{$\begin{array}{c}\mathrm{Ca} \\
0.004\end{array}$} & Mg & \multicolumn{2}{|c|}{$\mathbf{P}$} & $\mathrm{Fe}$ \\
\hline & \multicolumn{2}{|l|}{0.010} & \multicolumn{2}{|c|}{0.001} & \multicolumn{2}{|c|}{0.010} & & 0.004 & \multicolumn{2}{|c|}{0.002} & 0.002 \\
\hline plant 1 & \multicolumn{2}{|c|}{$15298.38 \pm 458.95$} & \multicolumn{2}{|c|}{$3897.24 \pm 85.73$} & \multicolumn{2}{|c|}{$3944.55 \pm 71$} & & $2058.22 \pm 47.34$ & \multicolumn{2}{|c|}{$915.45 \pm 22.89$} & $443.52 \pm 12.86$ \\
\hline plant 2 & \multicolumn{2}{|c|}{$25602.48 \pm 768.07$} & \multicolumn{2}{|c|}{$5650.18 \pm 113$} & \multicolumn{2}{|c|}{$3806.45 \pm 45.68$} & $\begin{array}{l}2309.26 \pm 46.19 \\
3529.95 \pm 74.13\end{array}$ & $1965.8 \pm 37.35$ & \multicolumn{2}{|c|}{$702.76 \pm 16.87$} & $743.89 \pm 22.32$ \\
\hline plant3 & $29009.41 \pm 928$. & & $6241.97 \pm$ & 18.6 & 4346.1 & \pm 69.54 & $3602.38 \pm 82.85$ & $1947.43 \pm 42.84$ & $1150.93=$ & 28.77 & $675.68 \pm 18.42$ \\
\hline plant 4 & $33304.26 \pm 965.8$ & & $7240.12 \pm 1$ & 5204 & 4849.3 & \pm 82.44 & $4543.73 \pm 95.42$ & $2350.96 \pm 56.42$ & 878.26 & 20.2 & $441.5 \pm 13.69$ \\
\hline plant 5 & $12523.58 \pm 388.2$ & & $2810.56 \pm$ & 53.4 & 1890.2 & \pm 28.35 & $1047.60 \pm 19.9$ & $1488.13 \pm 34.27$ & 1092.29 & 27.31 & $120.27 \pm 3.73$ \\
\hline plant 6 & $17225.55 \pm 516.7$ & & $4373.33 \pm \varepsilon$ & 7.47 & 3619.6 & \pm 57.92 & $2138.18 \pm 42.76$ & $2645.57 \pm 66.14$ & 1022.76 & 24.55 & $760.71 \pm 21.3$ \\
\hline plant 7 & $14035.03 \pm 407$ & & $3361.83 \pm$ & 70.6 & 4193. & $8 \pm 67.1$ & $1259.11 \pm 23.92$ & $2535.34 \pm 50.71$ & 1068.45 & 22.44 & $167.13 \pm 5.01$ \\
\hline plant 8 & $18639.95 \pm 559$. & & $3627.49 \pm \varepsilon$ & 3.43 & 3207.4 & \pm 48.11 & $3319.03 \pm 69.7$ & $1708.60 \pm 35.88$ & 984.20 & .59 & $215.52 \pm 6.03$ \\
\hline plant 9 & $15091.58 \pm 422.5$ & & $3512.01 \pm$ & 3.22 & 4180 & \pm 71.06 & $3358.88 \pm 63.82$ & $3251.8 \pm 81$ & $633.25=$ & .56 & $206.40 \pm 6.4$ \\
\hline plant10 & $12895.00 \pm 257$ & & $2796.88 \pm$ & 5.93 & 4903.4 & \pm 68.65 & $3187.47 \pm 66.9$ & $2223.01 \pm 41.92$ & $484.08=$ & 2.59 & $620.38 \pm 16.75$ \\
\hline plant 11 & $17976.42 \pm 413$. & & $3523.78 \pm$ & 72.9 & 4376 & \pm 65.65 & $3284.36 \pm 65.69$ & $2206.38 \pm 50.75$ & 709.65 & .03 & $260.99 \pm 7.83$ \\
\hline plant 12 & $18890.55 \pm 415$ & & $3975.80 \pm$ & 1.56 & 3638.7 & \pm 58.22 & $4700.99 \pm 84.62$ & $2792.54 \pm 50.27$ & 989.43 & 3.75 & $630.96 \pm 17.67$ \\
\hline plant 13 & $17584.78 \pm 404$ & & $3519.41 \pm$ & 7.42 & 3151 & 53.57 & $3295.43 \pm 72.5$ & $2250.72 \pm 51.77$ & 614.65 & 2.91 & $350.96 \pm 10.18$ \\
\hline plant14 & $25160.22 \pm 603$ & & $5847.39=$ & 99.4 & 3698. & \pm 55.47 & $3260.95 \pm 58.7$ & $2313.56 \pm 46.27$ & 463.5 & & $569.23 \pm 15.37$ \\
\hline Mean & 19516.94 & & 4312 & & 38 & & 3059.81 & 2267.01 & 836 & & 443.37 \\
\hline RSD & & & & & & & 34.44 & 19.85 & 2 & & 50.74 \\
\hline LOD & $\mathrm{Cl}$ & & $\mathrm{Sr}$ & & $\mathrm{Na}$ & $\mathrm{Mn}$ & B & $\mathrm{Zn}$ & $\mathrm{Cu}$ & Mo & SUM \\
\hline & 0.010 & & 0.002 & & 005 & 0.002 & 0.006 & 0.002 & 0.001 & 0.003 & \\
\hline plant 1 & $195.86 \pm 5.09$ & & $4.30 \pm 6.47$ & 94.9 & $0 \pm 2.37$ & $23.36 \pm 0.37$ & $24.39 \pm 0.78$ & $18.52 \pm 0.72$ & $2.83 \pm 0.11$ & $0.77 \pm 0.02$ & 29361.55 \\
\hline plant 2 & $305.56 \pm 6.42$ & & $6.41 \pm 6.67$ & 132.3 & $38 \pm 2.78$ & $31.67 \pm 0.6$ & $32.11 \pm 1.16$ & $19.16 \pm 0.73$ & $4.28 \pm 0.18$ & $0.97 \pm 0.03$ & 42784.05 \\
\hline plant3 & $331.92 \pm 8.3$ & & $9.36 \pm 7.27$ & 158.9 & $1 \pm 3.65$ & $38.25 \pm 0,77$ & $38.54 \pm 1.31$ & $22.82 \pm 0.87$ & $4.83 \pm 0.19$ & $1.02 \pm 0.03$ & 47839.64 \\
\hline plant 4 & $294.46 \pm 6.77$ & & $2.49 \pm 4.81$ & 194.4 & $1 \pm 5.64$ & $58.74 \pm 1.06$ & $41.86 \pm 1.3$ & $28.26 \pm 1.05$ & $6.14 \pm 0.23$ & $1.47 \pm 0.05$ & 54426.02 \\
\hline plant 5 & $102.36 \pm 2.76$ & & $0.79 \pm 2.1$ & 29.9 & $5 \pm 0.75$ & $7.23 \pm 0.16$ & $10.88 \pm 0.37$ & $10.28 \pm 0.41$ & $2.13 \pm 0.08$ & $0.59 \pm 0.02$ & 21216.91 \\
\hline plant 6 & $182.59 \pm 4.93$ & & $8.18 \pm 6.11$ & 71.4 & $7 \pm 1.72$ & $17.98 \pm 0.0$ & $22.71 \pm 0.77$ & $15.15 \pm 0.55$ & $2.76 \pm 0.1$ & $0.83 \pm 0.03$ & 32317.46 \\
\hline plant 7 & $109.29 \pm 2.95$ & & $3.51 \pm 3.58$ & 39.6 & $5 \pm 0.92$ & $14.09 \pm 0.3$ & $17.39 \pm 0.61$ & $20.59 \pm 0.74$ & $2.28 \pm 0.09$ & $0.91 \pm 0.03$ & 26948.18 \\
\hline plant 8 & $193.43 \pm 5.03$ & & $9.90 \pm 3.38$ & 60.9 & $4 \pm 1.46$ & $14.81 \pm 0.2 \varepsilon$ & $19.21 \pm 0.65$ & $18.35 \pm 0.72$ & $2.26 \pm 0.08$ & $0.74 \pm 0.02$ & 32141.89 \\
\hline plant 9 & $178.82 \pm 4.47$ & & $8.67 \pm 2.93$ & 92.2 & $9 \pm 1.94$ & $13.16 \pm 0.2 \varepsilon$ & $29.78 \pm 1.04$ & $16.74 \pm 0.69$ & $2.53 \pm 0.1$ & $0.85 \pm 0.03$ & 30677.06 \\
\hline plant10 & $280.76 \pm 5.9$ & & $37.71 \pm 5.7$ & 97.7 & $2 \pm 2.15$ & $15.37 \pm 0.3$ & $27.72 \pm 0.94$ & $19.52 \pm 0.76$ & $2.07 \pm 0.08$ & $0.90 \pm 0.03$ & 27791.99 \\
\hline plant 11 & $281.37 \pm 7.88$ & & $15.36 \pm 3$ & 101.4 & $15 \pm 2.54$ & $26.71 \pm 0.5$ & $23.61 \pm 0.78$ & $13.96 \pm 0.56$ & $2.53 \pm 0.1$ & $0.66 \pm 0.02$ & 32903.72 \\
\hline plant 12 & $262.93 \pm 6.05$ & & $6.75 \pm 5.92$ & 115.5 & $50 \pm 2.66$ & $39.46 \pm 0.75$ & $28.88 \pm 0.99$ & $12.23 \pm 0.45$ & $3.40 \pm 0.14$ & $0.90 \pm 0.03$ & 36319.02 \\
\hline plant 13 & $272.36 \pm 7.08$ & & $0.24 \pm 3.51$ & 91. & $02 \pm 2$ & $25.40 \pm 0.5$ & $22.78 \pm 0.77$ & $21.55 \pm 0.86$ & $3.55 \pm 0.14$ & $0.80 \pm 0.02$ & 31344.91 \\
\hline plant14 & $239.48 \pm 6.47$ & & $9.66 \pm 6.43$ & 148.5 & $8 \pm 3.86$ & $42.25 \pm 0.97$ & $20.99 \pm 0.71$ & $18.90 \pm 0.74$ & $3.58 \pm 0.15$ & $0.87 \pm 0.02$ & 42017.34 \\
\hline Mean & 230.80 & & 176.67 & & 2.08 & 26.32 & 25.78 & 18.29 & 3.23 & 0.88 & 34863.55 \\
\hline RSD & 31.03 & & 36.07 & & 4.67 & 54.42 & 31.82 & 24.94 & 36.62 & 23.48 & 25.70 \\
\hline
\end{tabular}

hyperaccumulate $\mathrm{N}(>12,500 \mathrm{mg} / \mathrm{kg}), \mathrm{S}(>1,890 \mathrm{mg} / \mathrm{kg})$, $\mathrm{P}(>463 \mathrm{mg} / \mathrm{kg}), \mathrm{Cl}(>102 \mathrm{mg} / \mathrm{kg}), \mathrm{Sr}(>80 \mathrm{mg} / \mathrm{kg})$, and $\mathrm{Mg}(>1,488 \mathrm{mg} / \mathrm{kg})$, and mean enrichment coefficients of E. sinica to the six elements totaled $42.88,34.37,7.81,4.38$, 2.16 , and 1.56, respectively, and the other elements yielded mean enrichment coefficients of $<1$.

\section{Prediction models for element transfer from soil to E. sinica}

Table 7 showed the prediction models for the essential elements. Multiple linear regression analysis identified $C_{\text {soil }}, \mathrm{pH}$, sand, silt, and $\mathrm{OM}$ as factors that best explained variability in $C_{\text {plant }}\left(R^{2}=39.2 \%-96.6 \%\right.$, $P<0.05)$. More than $76 \%$ of $\mathrm{Cu}, \mathrm{B}, \mathrm{Mo}, \mathrm{Na}, \mathrm{Mn}$, and $\mathrm{P}$ contents in E. sinica were explained by soil factors. These prediction models could be used to obtain reliable predictions of element contents in E. sinica herbaceous stems and therefore used to assess potential value or risk to humans. These models also contributed to regulation of E. sinica rhizosphere soils to ensure herb growth and quality safety. For example, based on the regression model 2, when grown on soil with high $\mathrm{Mn}$ factors, $\mathrm{Mn}$ content of E. sinica herbaceous stem can be reduced by raising soil $\mathrm{pH}$.

Fig. 1 showed the interrelation between the identified log $\left[C_{\text {plant }}\right]$ and its predicted value. Most predicted values fell within the $95 \%$ prediction interval, displaying the good accuracy for these models. Mean square error (MSE) values ranged from 0.029 to 0.679 for these prediction models (Table 7). Thus, these models were responsible predictors of element contents in E. sinica herbaceous stems.

These regression equations could also be used to evaluate the suitability of soils for herb safe production (Römkens et al., 2011). For example, according to Equation 6, an 
Cao, et al.

Table 5: Correlation coefficients between the basic compositions in soils and the elemental contents in plants

\begin{tabular}{|c|c|c|c|c|c|c|}
\hline plant & Sand & Silt & Clay & $\mathrm{pH}$ & OM & CEC \\
\hline $\mathrm{N}$ & $-0.574^{*}$ & $0.739^{\star *}$ & 0.433 & -0.462 & $0.763^{* *}$ & 0.053 \\
\hline K & $-0.581^{*}$ & $0.711^{* *}$ & 0.452 & -0.470 & $0.737^{* *}$ & 0.170 \\
\hline$S$ & -0.442 & 0.427 & 0.386 & 0.079 & 0.269 & -0.200 \\
\hline $\mathrm{Ca}$ & -0.277 & 0.414 & 0.187 & -0.266 & 0.400 & -0.099 \\
\hline $\mathrm{Mg}$ & 0.150 & -0.081 & -0.155 & -0.068 & -0.052 & 0.150 \\
\hline $\mathrm{P}$ & -0.118 & 0.270 & 0.046 & -0.077 & 0.395 & -0.341 \\
\hline $\mathrm{Fe}$ & -0.516 & 0.430 & 0.476 & -0.053 & 0.247 & 0.170 \\
\hline $\mathrm{Cl}$ & $-0.594^{*}$ & $0.670^{* *}$ & 0.484 & -0.100 & 0.431 & -0.116 \\
\hline $\mathrm{Sr}$ & $-0.551^{*}$ & 0.477 & 0.501 & -0.232 & 0.362 & 0.075 \\
\hline $\mathrm{Na}$ & $-0.553^{*}$ & $0.702^{\star \star}$ & 0.422 & -0.403 & $0.648^{\star}$ & 0.105 \\
\hline $\mathrm{Mn}$ & -0.481 & $0.641^{*}$ & 0.355 & $-0.575^{\star}$ & $0.759^{\star *}$ & 0.222 \\
\hline B & $-0.645^{*}$ & $0.763^{\star *}$ & 0.512 & -0.129 & $0.653^{*}$ & -0.290 \\
\hline $\mathrm{Zn}$ & -0.451 & 0.488 & 0.375 & -0.090 & 0.476 & -0.036 \\
\hline $\mathrm{Cu}$ & $-0.623^{*}$ & $0.779^{\star \star}$ & 0.479 & -0.432 & $0.855^{\star *}$ & 0.021 \\
\hline Mo & -0.499 & $0.568^{*}$ & 0.404 & -0.271 & $0.758^{* *}$ & -0.137 \\
\hline SUM & $-0.587^{*}$ & $0.745^{\star *}$ & 0.447 & -0.435 & $0.748^{* *}$ & 0.038 \\
\hline
\end{tabular}

*. Correlation is significant at the 0.05 level (2-tailed).

**. Correlation is significant at the 0.01 level (2-tailed).

Table 6: Correlation coefficients for the element contents between the plants and the soils

\begin{tabular}{|c|c|c|c|c|c|c|c|c|c|c|c|c|c|c|c|}
\hline \multirow[t]{2}{*}{ plant } & \multicolumn{15}{|c|}{ soil } \\
\hline & $\mathrm{Ca}$ & $\mathrm{Na}$ & K & $\mathrm{Fe}$ & $\mathrm{Mg}$ & Mn & $\mathbf{N}$ & $\mathrm{S}$ & $\mathbf{P}$ & $\mathrm{Sr}$ & $\mathrm{Zn}$ & $\mathrm{Cl}$ & B & $\mathrm{Cu}$ & Mo \\
\hline$N$ & $0.744^{* *}$ & 0.044 & $0.950^{* *}$ & $0.670^{* *}$ & $0.907^{* *}$ & $0.848^{* *}$ & $0.786^{* *}$ & -0.287 & $0.884^{* *}$ & 0.443 & $0.919^{* *}$ & 0.267 & -0.048 & $0.889^{* *}$ & 0.235 \\
\hline $\mathrm{K}$ & $0.762^{* *}$ & 0.180 & $0.981^{* *}$ & $0.566^{*}$ & $0.896^{* *}$ & $0.823^{* *}$ & $0.795^{* *}$ & -0.201 & $0.829^{* *}$ & 0.498 & $0.912^{* *}$ & 0.350 & 0.004 & $0.866^{* *}$ & 0.209 \\
\hline$S$ & 0.315 & 0.018 & 0.384 & 0.529 & 0.468 & $0.541^{*}$ & $0.589^{*}$ & -0.079 & 0.429 & 0.355 & 0.347 & 0.466 & -0.279 & 0.419 & 0.268 \\
\hline $\mathrm{Ca}$ & $0.647^{\star}$ & -0.266 & 0.455 & $0.852^{* *}$ & $0.686^{* *}$ & $0.537^{*}$ & $0.542^{*}$ & -0.434 & $0.730^{* *}$ & 0.433 & $0.551^{*}$ & 0.026 & -0.418 & $0.733^{* *}$ & 0.415 \\
\hline $\mathrm{Mg}$ & 0.171 & 0.353 & -0.068 & 0.176 & -0.017 & -0.036 & 0.146 & 0.324 & 0.018 & 0.101 & -0.060 & 0.084 & -0.199 & 0.095 & 0.612 \\
\hline$P$ & -0.158 & -0.155 & 0.028 & 0.049 & 0.062 & 0.063 & 0.033 & 0.037 & 0.008 & -0.136 & 0.234 & 0.263 & $0.979^{* *}$ & -0.095 & -0.526 \\
\hline $\mathrm{Fe}$ & $0.728^{* *}$ & 0.163 & 0.472 & 0.382 & $0.601^{*}$ & 0.346 & 0.406 & -0.127 & 0.481 & $0.993^{* *}$ & 0.435 & 0.405 & -0.161 & 0.466 & -0.016 \\
\hline $\mathrm{Cl}$ & $0.673^{* *}$ & -0.276 & $0.544^{*}$ & $0.720^{* *}$ & $0.741^{* *}$ & $0.611^{*}$ & 0.508 & -0.442 & $0.811^{* *}$ & $0.655^{*}$ & $0.589^{*}$ & 0.055 & -0.467 & $0.692^{* *}$ & 0.268 \\
\hline $\mathrm{Sr}$ & $0.788^{* *}$ & 0.162 & $0.585^{*}$ & 0.529 & $0.659^{*}$ & 0.494 & $0.538^{*}$ & -0.146 & $0.556^{*}$ & $0.922^{*+}$ & 0.512 & 0.531 & -0.189 & $0.566^{*}$ & 0.009 \\
\hline $\mathrm{Na}$ & $0.819^{* *}$ & -0.022 & $0.851^{* *}$ & $0.700^{* *}$ & $0.896^{* *}$ & $0.784^{* *}$ & $0.765^{* *}$ & -0.425 & $0.898^{* *}$ & $0.562^{*}$ & $0.820^{* *}$ & 0.215 & -0.323 & $0.922^{* *}$ & 0.366 \\
\hline $\mathrm{Mn}$ & $0.865^{* *}$ & 0.094 & $0.804^{* *}$ & $0.725^{* *}$ & $0.874^{* *}$ & $0.743^{* *}$ & $0.784^{* *}$ & -0.393 & $0.903^{* *}$ & 0.476 & $0.858^{* *}$ & 0.272 & -0.153 & $1.000^{* *}$ & 0.421 \\
\hline B & $0.564^{*}$ & -0.278 & $0.727^{* *}$ & $0.811^{* *}$ & $0.878^{* *}$ & $0.830^{* *}$ & $0.787^{* *}$ & -0.253 & $0.841^{* *}$ & 0.525 & $0.793^{* *}$ & 0.285 & -0.126 & $0.715^{* *}$ & 0.225 \\
\hline $\mathrm{Zn}$ & 0.290 & 0.064 & $0.668^{* *}$ & $0.582^{*}$ & $0.617^{*}$ & $0.885^{* *}$ & $0.800^{* *}$ & 0.077 & $0.535^{*}$ & 0.139 & $0.605^{*}$ & 0.391 & -0.125 & $0.546^{*}$ & 0.298 \\
\hline $\mathrm{Cu}$ & $0.696^{* *}$ & -0.049 & $0.906^{* *}$ & $0.718^{* *}$ & $0.941^{* *}$ & $0.901^{* *}$ & $0.853^{* *}$ & -0.220 & $0.932^{* *}$ & 0.425 & $0.966^{* *}$ & 0.241 & 0.005 & $0.896^{* *}$ & 0.308 \\
\hline Mo & 0.516 & 0.032 & $0.799^{* *}$ & $0.750^{* *}$ & $0.829^{* *}$ & $0.915^{* *}$ & $0.991^{* *}$ & -0.041 & $0.719^{* *}$ & 0.337 & $0.827^{* *}$ & 0.525 & 0.019 & $0.758^{* *}$ & 0.313 \\
\hline SUM & $0.786^{* *}$ & 0.045 & $0.933^{* *}$ & $0.741^{* *}$ & $0.933^{* *}$ & $0.859^{* *}$ & $0.825^{* *}$ & -0.285 & $0.905^{* *}$ & 0.513 & $0.914^{* *}$ & 0.313 & -0.102 & $0.914^{* *}$ & 0.292 \\
\hline
\end{tabular}

**. Correlation is significant at the 0.01 level (2-tailed).

*. Correlation is significant at the 0.05 level (2-tailed).

excessive case was employed to assess the soil fitness for production of Ma Huang by analyzing minimum sand and silt content and maximum of $\mathrm{Cu}_{\text {soil }}$ and $\mathrm{OM}$ content. In this paper, maximum $\mathrm{Cu}_{\text {soil }}$ (total content of soil elements correlated significantly with $\mathrm{Cu}$ in plants) and $O M$ content in soil measured $123,764.69$ and $22.11 \mathrm{~g} /$ $\mathrm{kg}$, respectively. On the other hand, minimum sand and silt values totaled 760.2 and $2 \mathrm{~g} / \mathrm{kg}$, respectively. When these values were used in Equation 6, Cu content of $5.73 \mathrm{mg} / \mathrm{kg}$ from E. sinica was calculated, this value is considerably lower than the green standard limit $(\leq 20$ $\mathrm{mg} / \mathrm{kg}$ ) for medicinal plants (MOC, 2004). Therefore, when soil $\mathrm{Cu}_{\text {soil }}$ content reaches $123,764.69 \mathrm{mg} / \mathrm{kg}$, Cu content in E. sinica will not exceed the safety limit. This finding further confirms the very low risk of producing E. sinica with $\mathrm{Cu}$ contents exceeding the safety limit. Therefore, Equation 6 can provide scientific basis for $\mathrm{Cu}$ monitoring of E. sinica.

\section{CONCLUSIONS}

The present study showed that 15 essential element characteristics in wild E. sinica and its rhizosphere soil, revealed the influences of rhizosphere soil on the elements in the herbs, and established prediction models for transfer of elements from soil to plant. The study results will assist in regulation of mineral elemental contents in E. sinica herbaceous stems. 

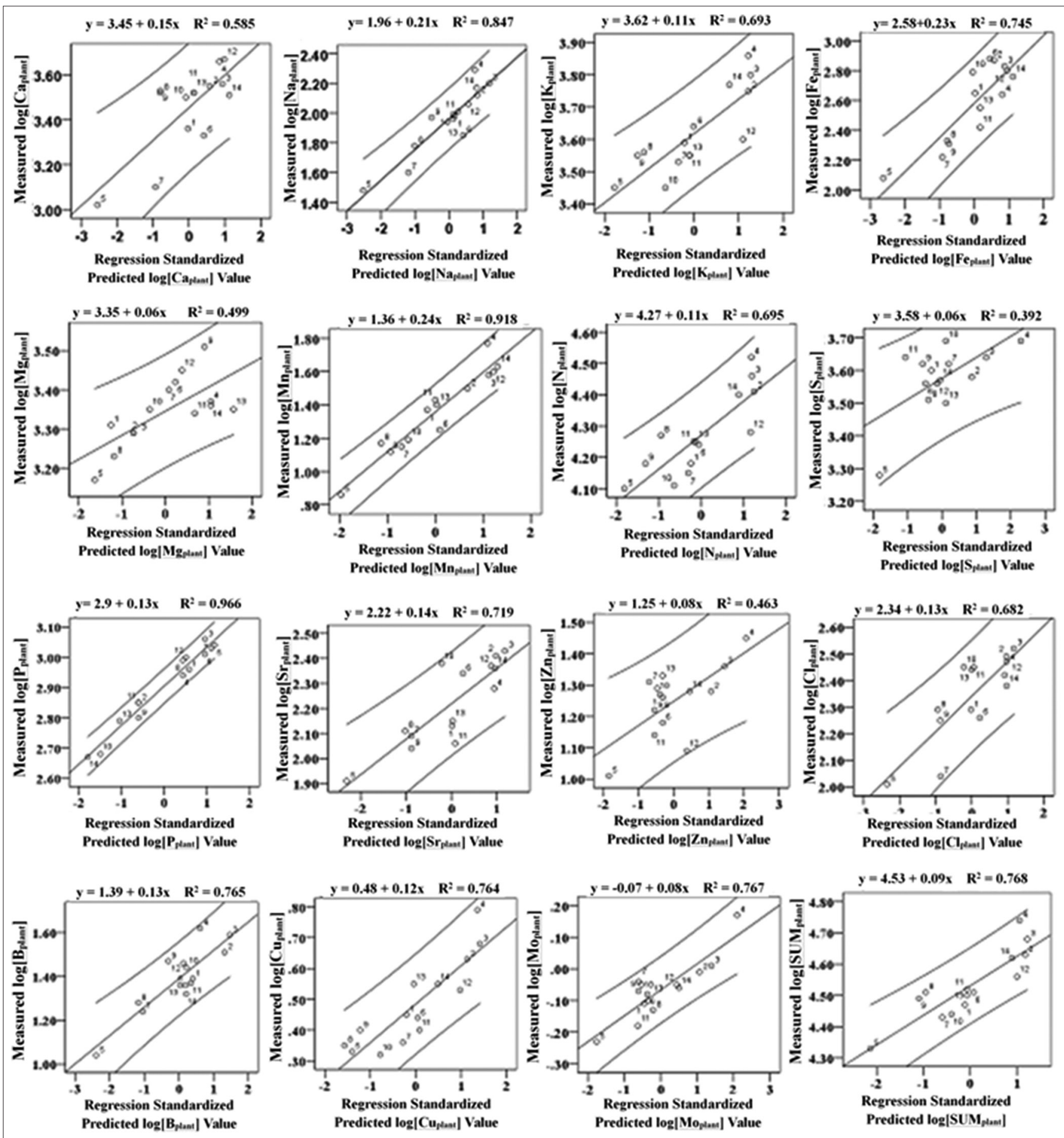

Fig 1. Relationship between the measured $\log \left[\mathrm{C}_{\text {plant }}\right]$ and the predicted $\log \left[\mathrm{C}_{\text {plant }}\right] . \mathrm{y}$ is measured logarithm value, and $\mathrm{x}$ is predicted logarithm value; $R^{2}$ is the regression equations coefficient of determination in Table 7.

\section{ACKNOWLEDGEMENT}

We are grateful to Professor Minsheng Yan from Northwest Normal University for morphological identification of the plant species. This study was supported by a grant (No. 81760687) from the National Natural Science Foundation of China.

\section{Authors' contributions}

All authors contributed to the work presented in this article. Zhe CAO and Yujie YIN performed the experiment. Yunsheng ZHAO, the corresponding author, designed the research plan, organized the study, coordinated the data analysis, and contributed to writing of the manuscript. Fuying MAO and Yanqun Peng wrote the paper. Xinhui 
Table 7: The prediction models for the element contents of $E$. Sinica $(n=14)$

\begin{tabular}{|c|c|c|c|c|c|}
\hline Code & Regression equations & $\mathbf{R}$ & $\mathbf{R}^{2}$ & $\mathbf{P}$ & MSE \\
\hline 1 & $\log [$ Pplant $]=1.321+0.959 \log [$ Psoil $]$ & 0.983 & 0.966 & 0.000 & 0.218 \\
\hline 2 & $\begin{array}{c}\log [\text { Mnplant }]=-0.763+0.639 \log [\text { Mnsoil }]-0.120[\mathrm{pH}]+ \\
0.011 \log [\text { silt }]+0.074 \log [\mathrm{OM}]\end{array}$ & 0.958 & 0.918 & 0.000 & 0.184 \\
\hline 3 & $\begin{aligned} \log [\text { Naplant }]= & 1.664+0.542 \log [\text { Nasoil] }-0.807 \log [\text { sand }]+ \\
& 0.220 \log [\text { silt }]-0.196 \log [\mathrm{OM}]\end{aligned}$ & 0.92 & 0.847 & 0.001 & 0.139 \\
\hline 4 & $\begin{array}{c}\log [\text { Moplant }]=-2.663+0.641 \log [\text { Mosoil }]-0.027 \log [\text { silt }]+ \\
0.019 \log [\mathrm{OM}]\end{array}$ & 0.876 & 0.767 & 0.002 & 0.029 \\
\hline 5 & $\begin{aligned} \log [\text { Bplant }]= & 5.288+0.225 \log [\text { Bsoil }]-1.723 \log [\text { sand }]+ \\
& 0.216 \log [\text { silt] }-0.193 \log [\mathrm{OM}]\end{aligned}$ & 0.874 & 0.765 & 0.007 & 0.055 \\
\hline 6 & $\begin{array}{c}\log [\text { Cuplant }]=2.111+0.233 \log [\text { Cusoil }]-0.950 \\
\log [\text { sand }]-0.027 \log [\text { silt }]+0.153 \text { log[OM }]\end{array}$ & 0.874 & 0.764 & 0.007 & 0.051 \\
\hline 7 & $\log [$ Feplant $]=0.106+0.540 \log [$ Fesoil $]$ & 0.863 & 0.745 & 0.000 & 0.679 \\
\hline 8 & $\log [$ Srplant $]=2.993+0.373$ log[Srsoil $]-0.853 \log [$ sand $]$ & 0.848 & 0.719 & 0.001 & 0.13 \\
\hline 9 & $\begin{array}{c}\log [\text { Nplant }]=6.378+0.287 \log [\text { Nsoil }]-1.151 \\
\log [\text { sand }]-0.128 \log [\text { silt }]+0.129 \log [\mathrm{OM}]\end{array}$ & 0.834 & 0.695 & 0.020 & 0.039 \\
\hline 10 & $\begin{array}{c}\log [\text { Kplant }]=5.460+0.266 \log [\text { Ksoil }]-1.041 \\
\log [\text { sand }]-0.089 \log [\text { silt }]+0.116 \log [\mathrm{OM}]\end{array}$ & 0.833 & 0.693 & 0.020 & 0.037 \\
\hline 11 & $\begin{array}{c}\log [\text { Clplant }]=2.936+0.374 \log [\text { Clsoil }]-0.797 \\
\log [\text { sand }]-0.003 \log [\text { silt }]\end{array}$ & 0.826 & 0.682 & 0.008 & 0.076 \\
\hline 12 & $\log [$ Caplant $]=1.597+0.399 \log [$ Casoil $]$ & 0.765 & 0.585 & 0.001 & 0.276 \\
\hline 13 & $\log [$ Mgplant $]=3.286+0.459$ log[Mgsoil $]$ & 0.706 & 0.499 & 0.005 & 0.049 \\
\hline 14 & $\log [$ Znplant $]=-1.165+0.591 \log [Z n s o i l]$ & 0.68 & 0.463 & 0.007 & 0.077 \\
\hline 15 & $\log [$ Splant $]=1.980+0.540 \mathrm{log}[$ Ssoil $]$ & 0.626 & 0.392 & 0.017 & 0.054 \\
\hline 16 & $\begin{array}{c}\log [\text { SUMplant }]=5.967+0.259 \text { log[SUMsoil] }-0.891 \\
\text { log[sand] }-0.052 \text { log[silt }]+0.047 \text { log[OM }]\end{array}$ & 0.876 & 0.768 & 0.006 & 0.029 \\
\hline
\end{tabular}

ZHANG performed statistical analysis and helped in interpretation of data and discussion of results. Junyu LIANG and Hongling TIAN collected the samples.

\section{REFERENCES}

Abourashed, E. A., A. T. El-Alfy, I. A. Khan and L. Walker. 2003. Ephedra in perspective-a current review. Phytother Res. 17: 703-712.

AFNOR. 1996. Qualité des sols. Agence Française de NORmalisation, Recueil de normes Française, AFNOR, Paris.

Akutsu, Y., T. Kono, M. Uesao, I. Hoshino, K. Murakami, T. Fujishiro, S. Imanishi, S. Endo, T. Toyozumi and H. Matsubara. 2012. Are additional trace elements necessary in total parenteral nutrition for patients with esophageal cancer receiving cisplatin-based chemotherapy? Biol. Trace Elem. Res. 150: 109-155.

CCME. 2012. Soil Quality Guidelines for the Protection of Environmental and Human Health. Canadian Council of Ministers of the Environment.

CEPA. 2006. Environmental Quality Evaluation Standard for Farmland of Edible Agricultural Products (HJ/T 332-2006). Chinese Environmental Protection Administration, Beijing.

Chen, X., X. Y. Zhang, R. R Zhang and K. C. Wang. 2009. Effects of $\mathrm{Mn}, \mathrm{Fe}, \mathrm{Zn}$, and $\mathrm{Cu}$ on growth and paeoniflorin content of Paeonia lactiflora. China J. Chin. Mater. Med. 34: 961-964.

Cheng, J. J., C. F. Ding, X. G. Li, T. L. Zhang and X. X. Wang. 2015. Rare earth element transfer from soil to navel orange pulp (Citrus sinensis Osbeck cv. Newhall) and the effects on internal fruit quality. PLoS One. 10(3): e0120618.

Han, J. P., S. L. Chen, W. S. Zhang and Y. Wang. 2006. Molecular ecology of Gardenia jasminoides authenticity. Chin. J. Appl.
Ecol. 17: 2385-2388.

Hong H., H. B. Chen, F. Xu, X. Y. Zang, D. H. Yang, X. Wang, S. Q. Cai and M. Mikage. 2011. Surveys on resources and varieties on Chinese markets of crude drug Mahuang. China J. Chin. Mater. Med. 36: 1129-1132.

Kabata-Pendias, A. and A. B. Mukhrjee. 2007. Trace elements from soil to humans. Springer, Berlin, pp. 87-415.

Kabata-Pendias, A. and H. Pendias. 2011. Trace elements in soils and plants. CRC Press, Boca Ratón.

Khasbagan. and Soyolt. 2007. Ephedra sinica Stapf (Ephedraceae): The fleshy bracts of seed cones used in mongolian food and its nutritional components. Econ. Bot. 61(2): 192-197.

MOC. 2004. WM/T 2-2004, Green Standards of Medicinal Plants and Preparations for Foreign Trade and Economy. Ministry of Commerce of the People's Republic of China, Beijing.

MOA. 1988. NY/T85-1988, Method for Determination of Soil Organic Matter. Ministry of Agriculture of the Peopl's Republic of China, Beijing.

MOA. 2006a. NY/T 1121.3-2006. Soil Testing Part 3: Method for Determination of Soil Mechanical Composition. Ministry of Agriculture of the Peopl's Republic of China, Beijing.

MOA. 2006b. NY/T 1121.5-2006. Method for Determination of Soil Cation Exchange Capacity in Calcareous Soil. Ministry of Agriculture of the Peopl's Republic of China, Beijing.

MOA. 2007. NY/T1377-2007. Determination of $\mathrm{pH}$ in Soil. Ministry of Agriculture of the Peopl's Republic of China, Beijing.

Nasim, S. A. and B. Dhir. 2010. Heavy metals alter the potency of medicinal plants. Rev. Environ. Contam. Toxicol. 203: 139-149.

Ohkama-Ohtsu, N. and J. Wasaki. 2010. Recent progress in plant nutrition research: Cross-talk between nutrients, plant physiology and soil microorganisms. Plant Cell Physiol. 51(8): $1255-1264$ 
Pharmacopoeia. 2015. Pharmacopoeia of the People's Republic of China. Pharmacopoeia of the P. R. China. Vol. 1. China Medical Science Press, Beijing, pp. 320-321.

Qin, J. F. 2011. The research of trace elements of Chinese medicine in China III. Trace element: Material basis of quantifying property and efficacy of Chinese medicine. Guangdong Trace Elem. Sci. 18(1): $1-10$

Römkens, P. F., D. J. Brus, H. Y. Guo, C. L. Chu, C. F. Chiang and G. F. Koopmans. 2011. Impact of model uncertainty on soil quality standards for cadmium in rice paddy fields. Sci. Total Environ. 409: 3098-3105.

Shen, G. M. 1995. Distribution and evolution of the genus Ephedra in China. Acta Bot. Yunnanica. 17: 15-20.

Singh, V. and A. N. Garg. 1997. Availability of essential trace elements in Ayurvedic Indian medicinal herbs using instrumental neutron activation analysis. Appl. Radiat. Isot. 48: 97-101.

Suchacz, B. and M. Wesolowski. 2013. Classification of herbal mixtures on the basis of some metals content using pattern recognition techniques. J. Trace Elem. Med. Bio. 27: 168-170.
Sun, J. B., Y. G. Gao, P. Zang, H. Yang and L. X. Zhang. 2013. Mineral elements in root of wild Saposhnikovia divaricate and its rhizosphere soil. Biol. Trace Elem. Res. 153: 363-370.

Tuo, F., D. H. Li, F. Q. Zhou, J. H. Luo, H. Tuo and X. Z. Kong. 2010. Determination of trace elements in Chinese medicinal plants by instrumental neutron activation analysis. J. Radioanal. Nucl. Chem. 284: 507-511.

Wang, F. 2012. Trace element research in China: Present and future. Chin. Bull. Life Sci. 24: 713-730.

WHO. 1998. Quality Control Methods for Medicinal Plant Materials. World Health Orgainzation Offset Publication, Geneva.

Xin, G. Z., B. Hu, Z. Q. Shi, J. Y. Zheng, L. Wang, W. Q. Chang, P. Li, Z. P. Yao and L. F. Liu. 2015. A direct ionization mass spectrometry-based approach for differentiation of medicinal Ephedra species. J. Pharm. Biomed. 117: 492-498.

Zhang, X.Y., Y. Y. Sui, X. D. Zhang, K. Meng and S. J. Herbert. 2007. Spatial variability of nutrient properties in black soil of northeast China. Pedosphere. 17(1): 19-29. 